\title{
APPLICATION OF THE ELECTRICAL (GEOPHYSICAL) METHOD FOR THE IDENTIFICATION OF THE SEALED BEVEL IN THE COASTAL REGION OF WALIDIA PROVINCE OF EL JADIDA - MOROCCO
}

\author{
$H$. ELFJIJI $^{* 1}, A$. BOUKDIR ${ }^{1}$ et $A$. ZITOUNI ${ }^{1}$ \\ 1 : Faculté des Sciences et techniques, Université Sultan Moulay Slimane, Béni Méllal, Morocco
}

\begin{abstract}
The Walidia area knows a great development of agricultural, industrial, maritime activities and a very great demographic expansion. This development is accompanied by a growing demand for water. On the other hand, any intense abstraction of fresh water at a coastal aquifer capture field causes a decrease in groundwater flow and a lowering of the piezometric surface. There is therefore a danger of advancing towards the land of the saltwater bevel and salinization of groundwater which is gradually loaded into mineral salts and can reach abnormally high levels.

This work deals with the application of geophysics by electrical sounding method to the in-depth study of the freshwater-salt water interface (salted bevel) on the one hand and the study of the lateral and vertical evolution of the geometry of the different aquifers.

The principle of the method is, when performing an electrical survey, to research how varies, at a given point on the surface, the resistivity of the subsoil vertically. For this one executes in a same place a succession of measurements, increasing each time the dimensions of the device and thus the depth of investigation which is proportional to them. At this site, we explore a slice of ground increasingly thick and thus highlights the changes in geological constitution along the vertical.
\end{abstract}

The electrical soundings were carried out with the classic Schlumberger device.

The interpretation and the exploitation of the data of the electric soundings carried out made it possible to :

- Follow the evolution of the salted bevel roof,

- Draw the upstream limit (marine invasion) of salted bevel Hauterivian, on the one hand, and Valanginian and Jurassic on the other hand,

- Follow the roof structure of Dridrat limestone (Hauterivien) and limestones of Valanginien and Upper Jurassic,

- Draw the map of the marl roof of Safi (Hauterivian) constituting the impermeable substratum of Dridrat limestones.

- KEYWORDS : Geophysical prospecting, electrical soundings, groundwater aquifers, saltbee, freshwater, saltwater, piezometric surface, limestones, marls, coastal region of Walidia, El Jadida, Morocco

* haelfjiji@yahoo.fr 


\section{I- INTRODUCTION}

In recent years, the mastery of irrigation has become synonymous with safety and success for the farm. In the Doukkala, the use of groundwater for irrigation, in particular, has become increasingly important. The main aquifer of the Walidia Sahel region (Lower Cretaceous limestones) is subject to subterranean marine invasion downstream. From where the will of the managers to know, with precision, the importance of the invaded zone, with a view to a reasoned exploitation.

The present work highlights the contribution and contribution of geophysical prospecting by the electrical survey method applied to the study of the coastal region of Walidia. The use of these geophysical methods for the detection of water, whether in continuous aquifers or in fissured environments, contributes, in the same way as the geomorphological analysis and the examination of aerial photos or satellite images carried out in advance. , to select one or more drill sites with a maximum chance of success.

\section{II- PRESENTATION OF THE STUDY AREA}

\section{II-1 Geographic location (fig. 1)}

The study area is located $23 \mathrm{~km}$ north-east of the city of Walidia in the province of El Jadida. With an area of about $170 \mathrm{~km} 2(28 \mathrm{~km}$ x $6 \mathrm{~km})$, this area is located, more exactly, in the Walidia sahel in the form of a low plain formed of a set of plio-quaternary platforms.

\section{II-2 Geology (fig. 2)}

Plio-Quaternary deposits consist of detrital and marine formations:

- Sandstone-limestone slabs;

- coarse bio-detritic limestones;

- Shell sands, more or less indurated;

- Clay sands.

The Plioquaternary ensemble, whose thickness is between a few meters and more than 100 meters, rests on the Lower Cretaceous formations. The following stratigraphic levels are observed from top to bottom:

- Upper Hauterivian: red plastic clays and at the base a level of calcareous sand, sometimes conglomeratic;

- Middle Hauterivian: crystalline limestone, sometimes with clayey pastures (Dridrat limestone);

- Lower Hauterivian: marls, gray or green clays with limestone levels (marl of Safi),

- Valanginian: limestone crystalline, sometimes marly ;

- Valanginien : calcaire cristallin, parfois marneux,

- $\quad$ Berriasian: gray to blue plastic clays;

- Upper Jurassic: anhydrite with limestone levels, sometimes dolometic.

\section{II-3 Hydrogeology}

The recent formations of the Plioquaternary contain a shallow water table, exploited by a battery of shallow wells. The piezometric surface is at absolute elevations between +5 and $+15 \mathrm{~m}$. The alimentation is ensured by the infiltration of the rains. Locally, this aquifer can feed the underlying aquifers, when the impervious level of the Upper Hauterivian has disappeared by pre-quaternary erosion.

An underground aquifer develops in the limestone of Dridrat, with a power of about 30 m. This aquifer is fed, at the same time, by outcrops to East and South-West Zemmamra, Cape Cantin), and by vertical drainage and karst conduits from the plio-quaternary aquifer system. The two tablecloths are sometimes confused near the shore. 
The aquifer of Dridrat, sometimes communicates in depth, with valanginian limestones (10 to $50 \mathrm{~m})$. However, the marls of Safi, more or less impervious and variable thickness (2 to $30 \mathrm{~m}$ ) can constitute a substratum to the aquifer of Dridrat.

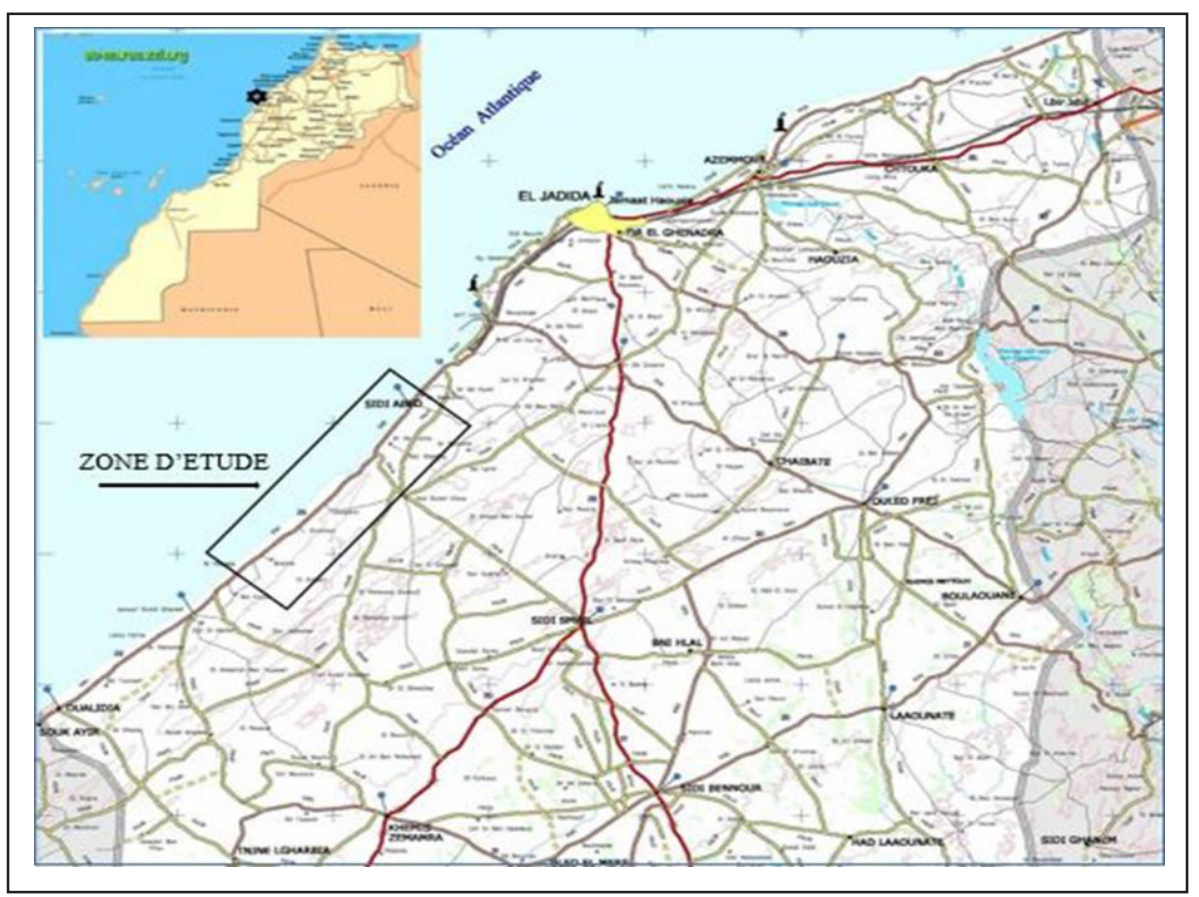

Fig.1 . Situation of the study area

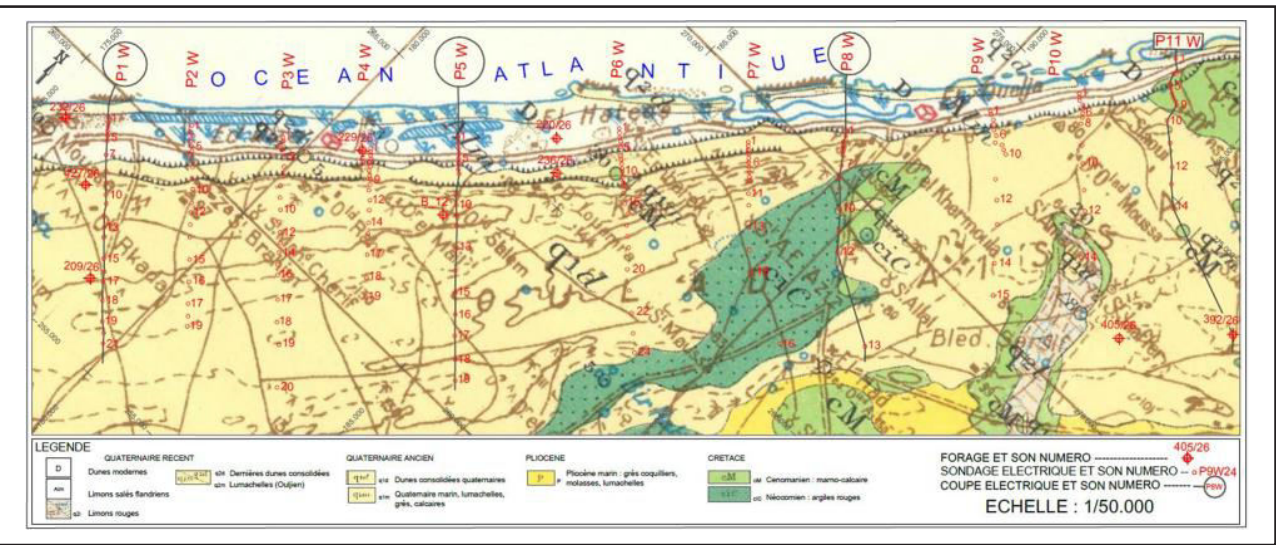

Fig.2. Geological map of the study area with location of soundings and power cuts 
The sketch below (Figure 3) presents in a synthetic way the distribution of aquifer geological formations and their mode of operation.

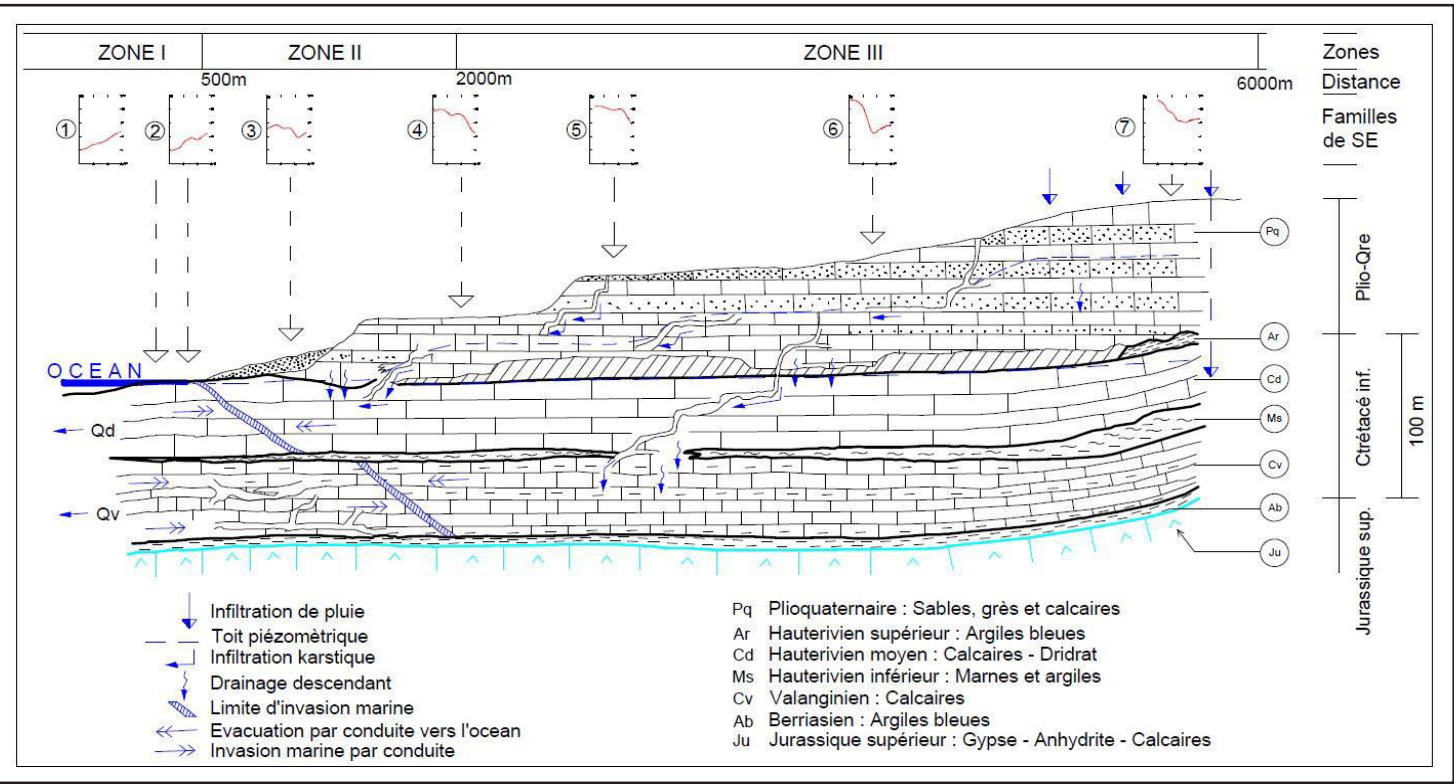

Fig.3. Hydrogeological diagram of the coastal basin of Walidia and the different families of Electrical Surveys

\section{III- METHOD OF ELECTRICAL SURVEYS (SE)}

\section{III-1 Purpose of the method of SE}

The use of electric prospecting method, allows to "visualize" the invaded areas in salt water and their lateral and vertical extension. In addition, this study results in the location and stratigraphic identification of two aquifer systems (Dridrat and Valanginien) and their hydrogeological boundaries.

Ultimately, the combination of geophysics and hydrogeological synthesis allows a good definition of the geometry of the Lower Cretaceous aquifer and a better understanding of the freshwater / saltwater system of the Walidia sahel.

\section{III-2 Principle of the method of SE}

The principle of the method is, when conducting an electrical survey, to research how varies, at a given point on the surface, the resistivity of the subsoil vertically. For this one executes in a same place a succession of measurements, increasing each time the dimensions of the device and thus the depth of investigation which is proportional to them. At this site, we explore a slice of ground increasingly thick and thus highlights the changes in geological constitution along the vertical. The electrical soundings were carried out with the classic Schlumberger device.

We obtain the apparent resistivity ( $\boldsymbol{\rho a}$ ) of a certain volume of ground:

$$
\rho a=\Delta V / I[2 \Pi(1 / A M-1 / A N-1 / B M+1 / B N)],
$$

We have : $\boldsymbol{\rho} \boldsymbol{a}=(\boldsymbol{\Delta V} / \mathbf{I}) \cdot \boldsymbol{K} \quad$ with $\quad K=2 \Pi(1 / A M-1 / A N-1 / B M+1 / B N)$

I : current intensity injected (electrodes A and B) 
$\Delta \mathrm{V}$ : the d.d.p. (potential difference between $\mathrm{M}$ and $\mathrm{N}$ )

$\mathrm{K}$ : geometric coefficient $\mathrm{f}(\mathrm{AMNB})$

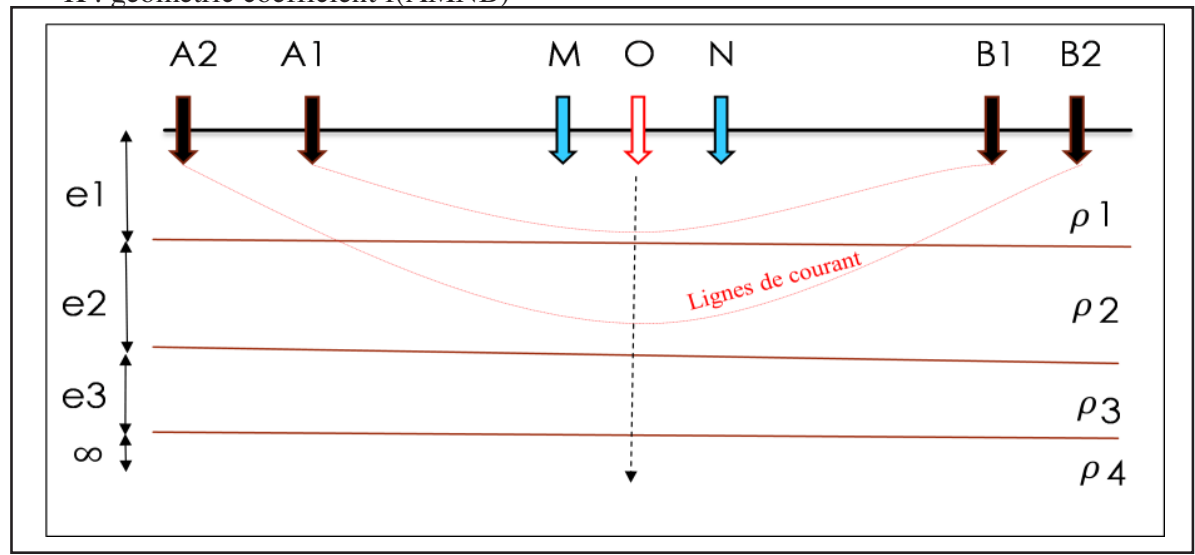

Fig.4. Diagram of the principle of electrical sounding in Schlumberger device

\section{III-3 Processing of diagrams of SE}

The quantitative interpretation of the measurements, previously carried out on a bilogarithmic diagram, begins with the smoothing of the curves, then by semi-automatic method, one carries out the inversion of the data. The model obtained is then corrected by successive approximations until the identification of the geological layers. The comparison of these results with those of boreholes, if any, allows a good estimate of true resistivities.

It should be noted, however, that the theoretical scheme of interpretation thus presented considers that the geological formations explored are tabular and isotropic.

\section{IV- RESULTS OBTAINED}

\section{IV-1 Analysis of diagrams of SE}

The mapping of the electrical soundings carried out with the established hydrogeological diagram makes it possible to group the SEs into a "typical" family set. Each family is characteristic of a specific electrical situation.

This correlation was based on drilling data, where available. Figure 5 summarizes the reference ES diagrams to illustrate the electrical evolution observed from shore to inland. 
Table $\mathbf{n}^{\circ}$ 1. The main electrical levels highlighted by electrical soundings

\begin{tabular}{|c|c|c|c|c|c|}
\hline $\mathrm{N}^{\circ}$ & $\begin{array}{l}\text { Electrical } \\
\text { levels }\end{array}$ & $\begin{array}{c}\text { Resistivity } \\
\text { (ohm.m) }\end{array}$ & $\begin{array}{c}\text { Thickness } \\
\text { (m) }\end{array}$ & Nature & $\begin{array}{c}\text { Marine } \\
\text { invasion } \\
\text { (near the } \\
\text { shore) }\end{array}$ \\
\hline 1 & $\begin{array}{c}\mathrm{C} 0, \mathrm{R} 0, \mathrm{C} 1 \\
\mathrm{R} 1\end{array}$ & $<4$ & \multirow{8}{*}{ variable } & $\begin{array}{l}\text { Plio-quaternary } \\
\text { Salty Dridrat } \\
\text { Salted Valanginian }\end{array}$ & Yes \\
\hline 2 & $\begin{array}{c}\mathrm{C} 0, \mathrm{R} 0, \mathrm{C} 1, \\
\mathrm{R} 1\end{array}$ & $30-130$ & & Plio-quaternary & No \\
\hline & $\mathrm{Rd}$ & $140-600$ & & $\begin{array}{l}\text { Dridrat Limestones } \\
\text { (Middle Highlander) }\end{array}$ & No \\
\hline 4 & $\mathrm{Rv}$ & $100-250$ & & $\begin{array}{l}\text { Limestones marl } \\
\text { (Valanginien) }\end{array}$ & No \\
\hline 5 & $\mathrm{Cv}$ & 2,6 & & $\begin{array}{l}\text { Limestones marl } \\
\text { (Valanginien) }\end{array}$ & Yes \\
\hline 6 & $\mathrm{Rp}$ & $>40$ & & \multirow{2}{*}{$\begin{array}{l}\text { Blue clays (Berriasian) } \\
\text { and gypsum formations } \\
\text { (Jurassic sup.) }\end{array}$} & \multirow{3}{*}{ No } \\
\hline 7 & $\mathrm{Cp}$ & 32 & & & \\
\hline 8 & $\mathrm{Rj}$ & $>75$ & & $\begin{array}{l}\text { Limestone anhydrite } \\
\text { (Jurassic sup.) }\end{array}$ & \\
\hline
\end{tabular}

It should be noted that formation lithology is no longer the only factor conditioning the value of resistivity. 

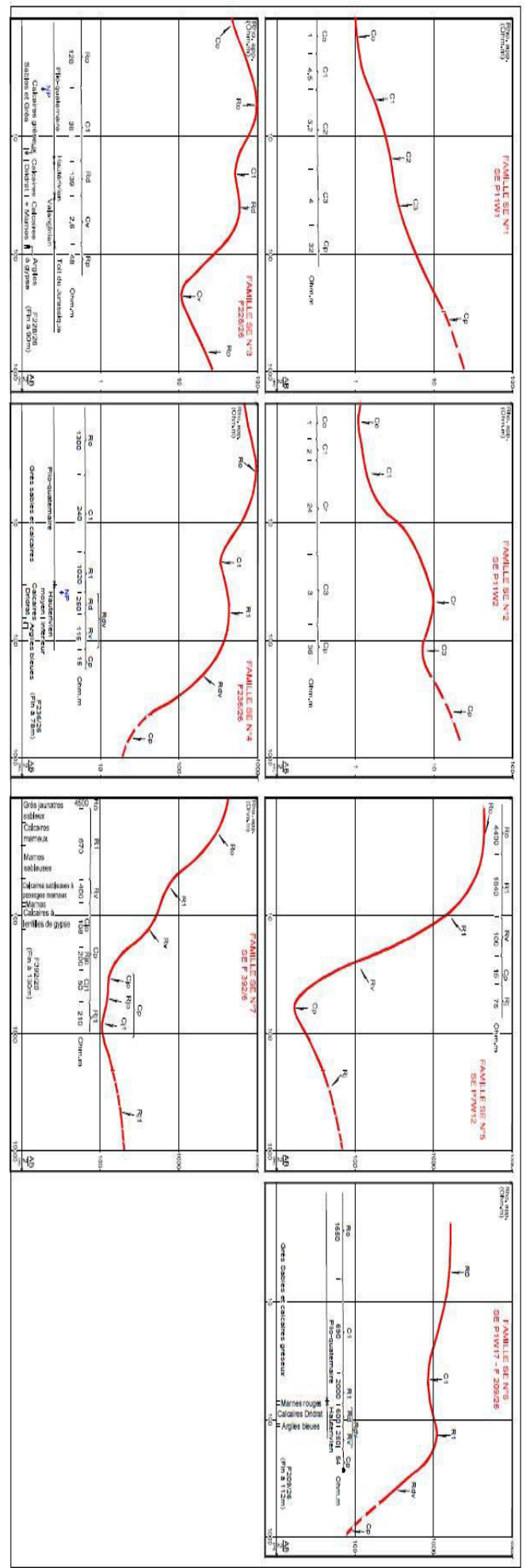

Fig. 5. The different families representative of electrical soundings 


\section{IV-2 Geoelectric cuts}

Four profiles or geoelectric sections were sent perpendicular to the shore. Their direction is approximately NO-SE. (Fig. 6).

These sections were drawn at the same horizontal and vertical scale (/5.000) so that the dipping of the layers and the shape of the salted bevel are presented without any deformation.

The examination of geoelectric sections presents, in a schematic way (Fig. 7), the following information:

- The marine invasion is wider in the South-West (2000-3500m) than in the North-East (500-900m);

- The highlighting of two stepped salt bevels. The upper bevel, having a gentle slope, corresponding to the limestone of Dridrat (Middle Hauterivian) and the lower bevel with very steep slope, corresponding to the marly limestones of Valanginien;

- The very important rise of the Jurassic formations towards North and North-East accompanied by a reduction, or an erosion of the formations hauteriviennes;

- $\quad$ Plio-Quaternary formations may be in direct contact with Valangian limestones.
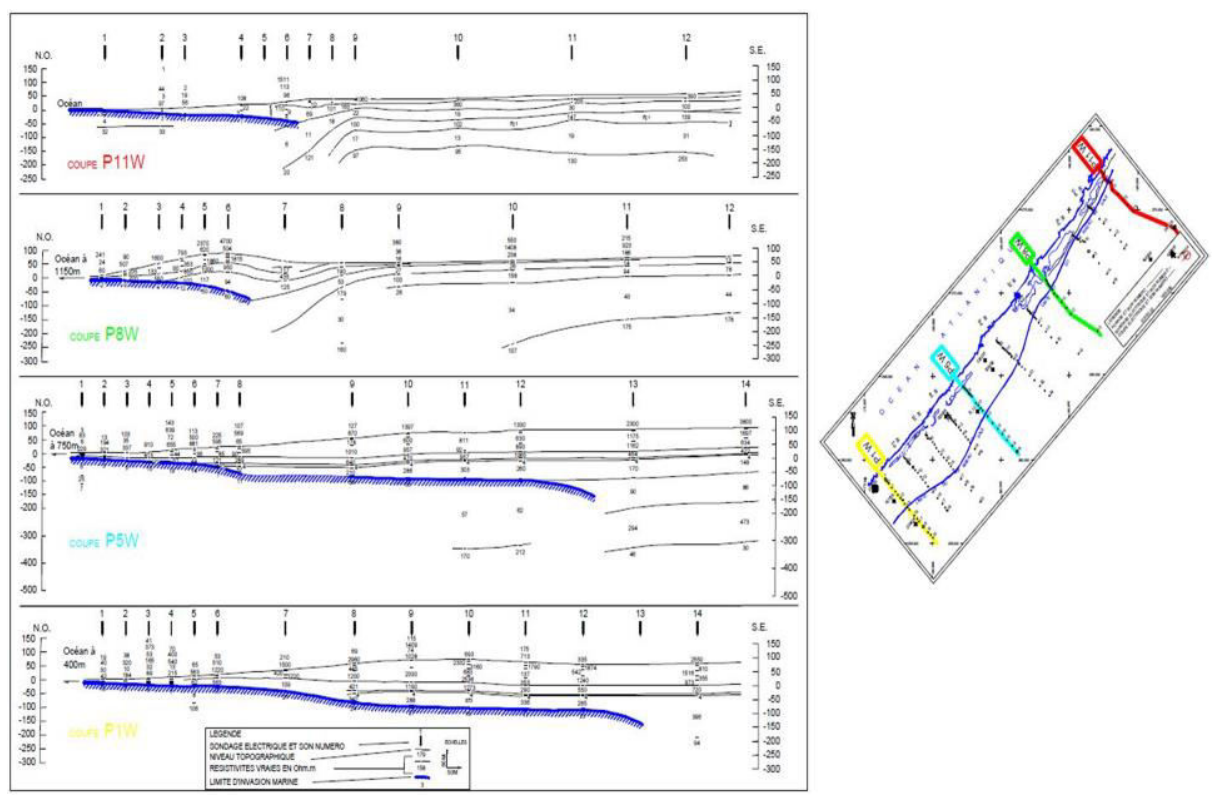

Fig. 6. Geoelectric cuts at the invasion zone marine 


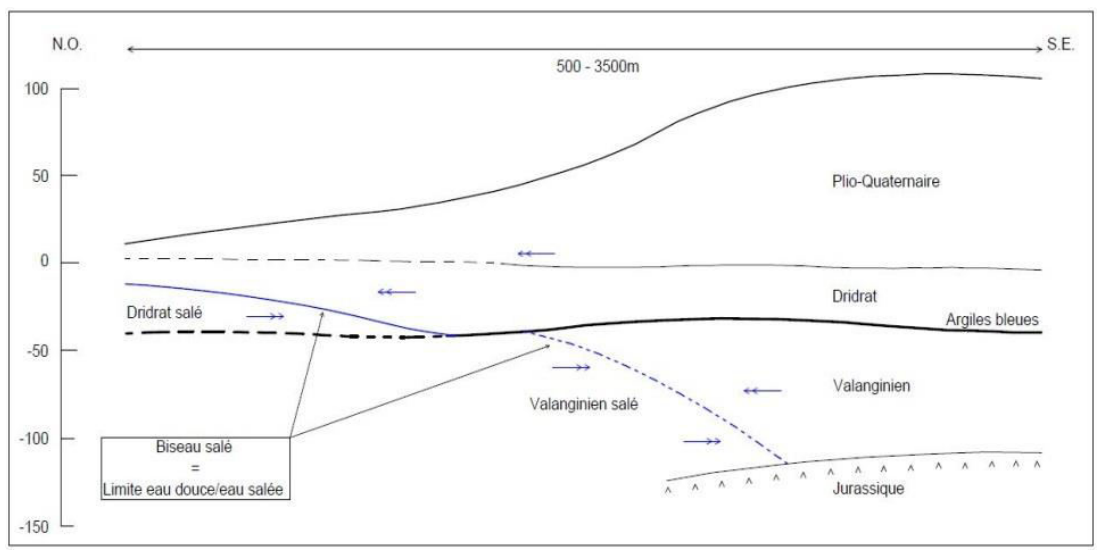

Fig.7. Schematic section of the marine invasion

\section{IV-3 Presentation of interpretative maps}

The results obtained by correlations of the geoelectric cuts made it possible to establish the following documents:

- $\quad$ Map of the isohypses of the limestone roof of Dridrat (Middle Hauterivian);

- Map of the isohypses of the marl roof of Safi (Lower Hauterivian);

- Map of the isohypses of the limestone roof of Valanginien and Upper Jurassic (Safi mare wall);

- $\quad$ Map of the salted bevel roof;

- $\quad$ Synthesis map.

\section{IV-3-1 Map of the isohypses of the roof of the limestone of Dridrat (Fig. 8)}

This document corresponds to the outline of the isohypses of the roof of the resistance set $\mathrm{Rd}$, located below the deposits attributed to the Plio-Quaternary. It is, in fact, the roof of limestones of Dridrat, and as the case, the surface of erosion pre-quaternary.

This document shows:

- The presence, in the western part of the study area (near the shore), of a narrow, elongated depression along a SO-NE direction. At the bottom of this depression, the roof of the limestone of Dridrat is located with dimensions lower than 0 ( $\mathrm{z}=$ 0 to $-20 \mathrm{~m})$;

- Towards the south-west, the roof of the Dridrat limestones shows a fairly regular morphology that rises to the surface, going up to grades greater than $+70 \mathrm{~m}$;

- On the south-east side of the depression, the roof surface of the Dridrat limestones narrows to the northeast due to the rise of the Jurassic formations. 


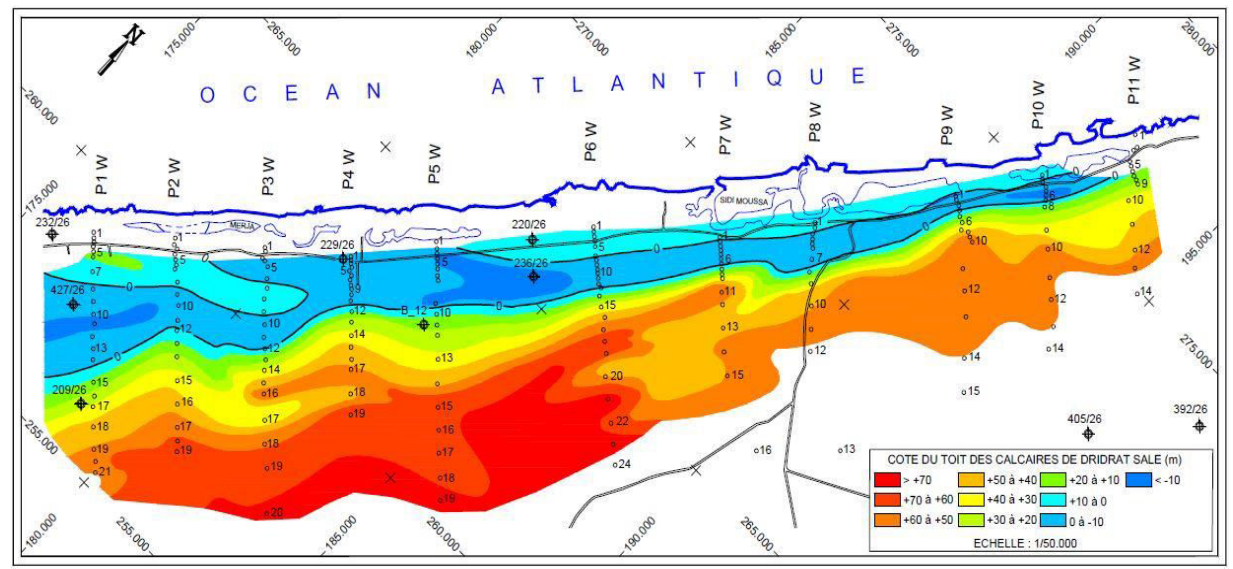

Fig.8. Map of the isohypses of the roof of the limestone of Dridrat (Middle Hauterivian)

\section{IV-3-2 Map of the isohypses of the roof of the marls of Safi (Fig. 9)}

This map gives an idea of the behavior of the marl roofs of Safi (Lower Hauterivian) which can play the role of an impermeable substratum at the base of Dridrat limestones. This substratum is intercalated between the Dridrat limestones of the Middle Hauterivian (resistant Rd) and the marly limestones of the resistant level Rv (Valanginian with fresh water) or the conducting level $\mathrm{Cv}$ (Valanginian salty).

This map shows:

- A depression can be pronounced, located between the contour level 0 and the coastal road Safi-El Jadida. This depression is extended in the direction SO-NE;

- In the southern part of the study area (south of the P6W profile), the roof of the marls of Safi draws an ascending trough structure towards the East

- The presence of a boundary, between the profiles P6W and P7W to the North-East of which, the roof of the marl becomes undetectable by the electrical soundings.

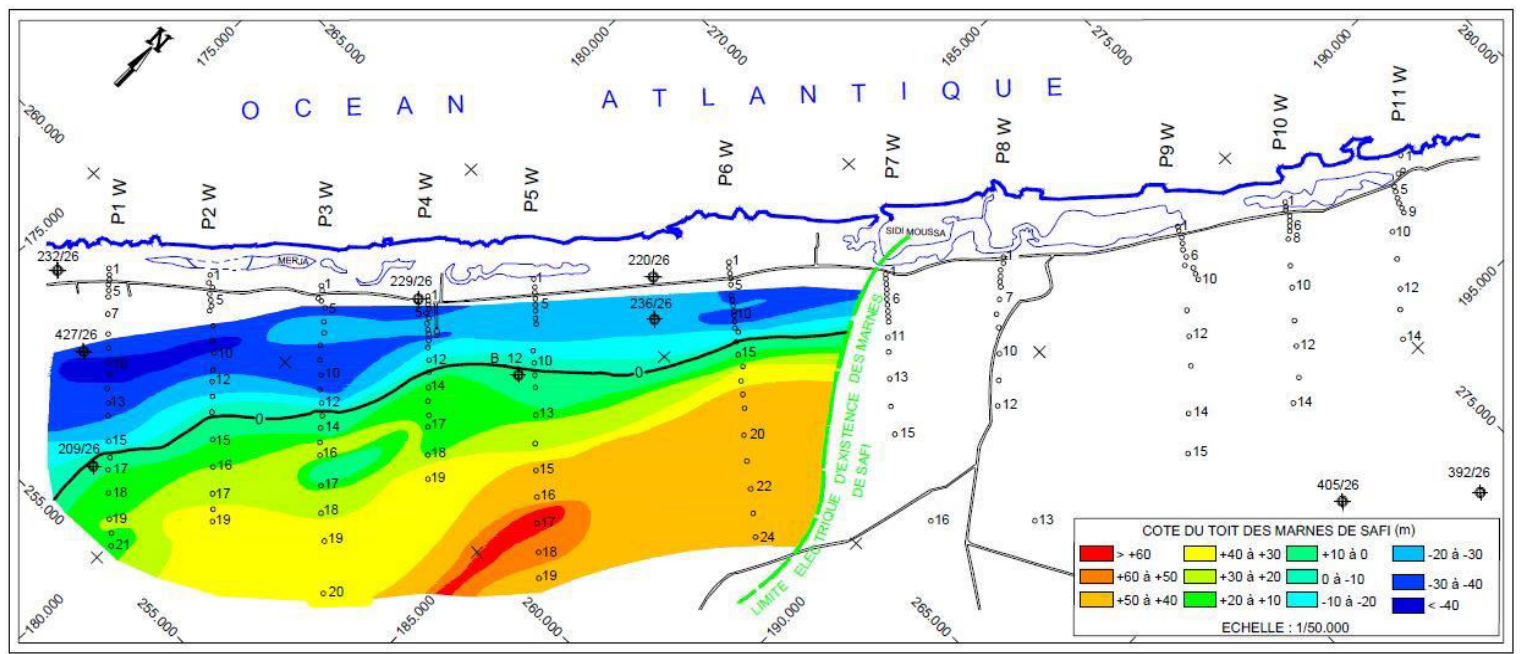

Fig.9. Map of the isohypses of the marl roof of Safi (Lower Hauterivien) 


\section{IV-3-3 Map of the isohypses of the limestone roof of the Valanginian and Upper Jurassic}

This map (Fig. 10) corresponds to the marl wall of Safi. It gives an idea of the roof morphology of Valangian limestones (Rd) and resistant formations of the Upper Jurassic (Rp).

On this map, the roof of the Valanginien and Upper Jurassic has a structure, oriented SO-NE, which goes from the northwest $(<-50 \mathrm{~m})$ to the southeast (rating $>+40 \mathrm{~m})$. Northeast of the profile P6W, there is the limit beyond which the highlighting of the marls of Safi becomes very difficult.

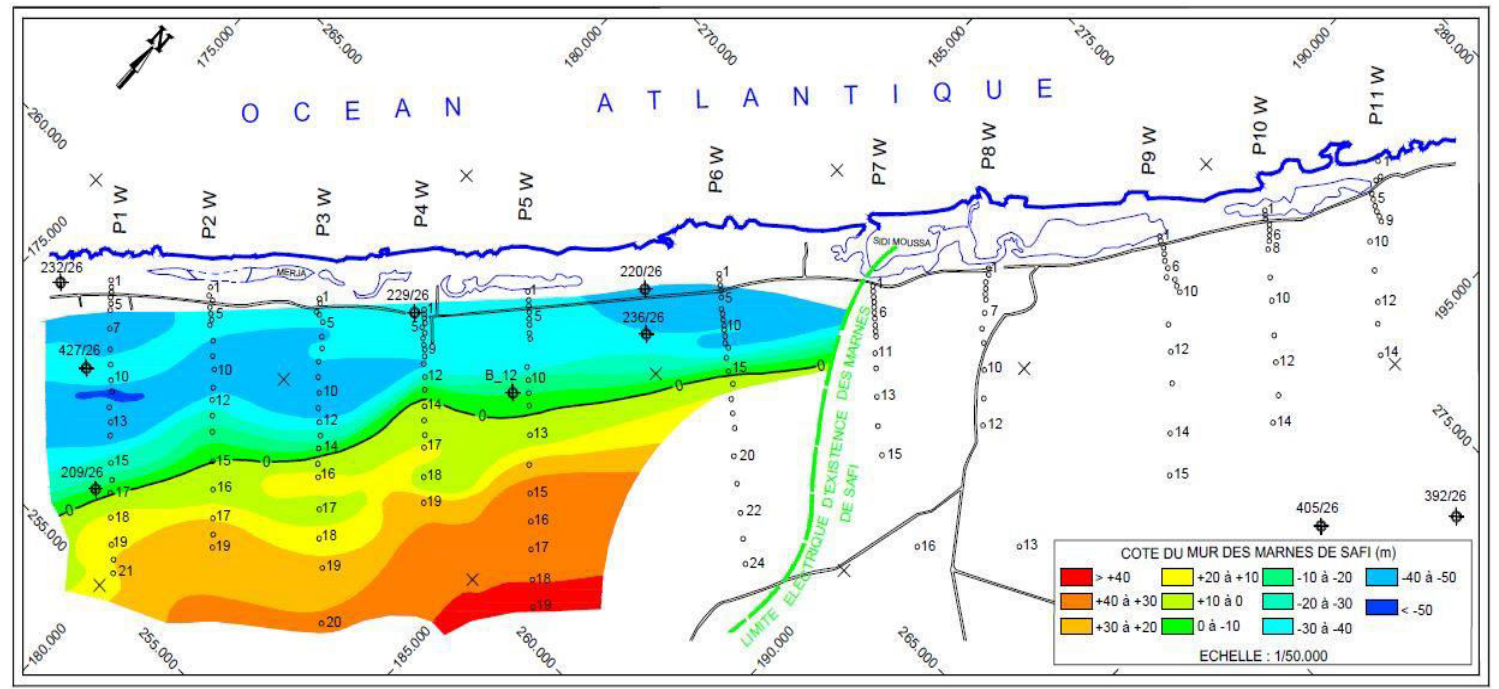

Fig.10. Map of the isohypses of the limestone roof of Valanginien and Upper Jurassic (Safi mare wall)

\section{IV-3-4 Salted bevel roof map (Fig. 11)}

This map, drawn from the elevations on the geo-electric sections, gives an idea of the shape of the roof surface of the salt wedge.

On this map we note the following observations:

- The presence of a salt wedge boundary along the shore. In the northeastern part, this limit is located at a short distance from the shore $(900 \mathrm{~m})$ whereas in the southwestern part this distance can exceed $3000 \mathrm{~m}$;

- The roof of the salted bevel is characterized by:

$>$ A first rise, ranging from -110 to -20 , which would be assimilated to the invasion of the carbonate formations of the Valanginien;

$>$ A second ascent, ranging from -20 to the sea coast for a distance of about $1000 \mathrm{~m}$. The latter, less clear than the first, would indicate the salt invasion in the higher levels, attributed to the limestones of Dridrate. 


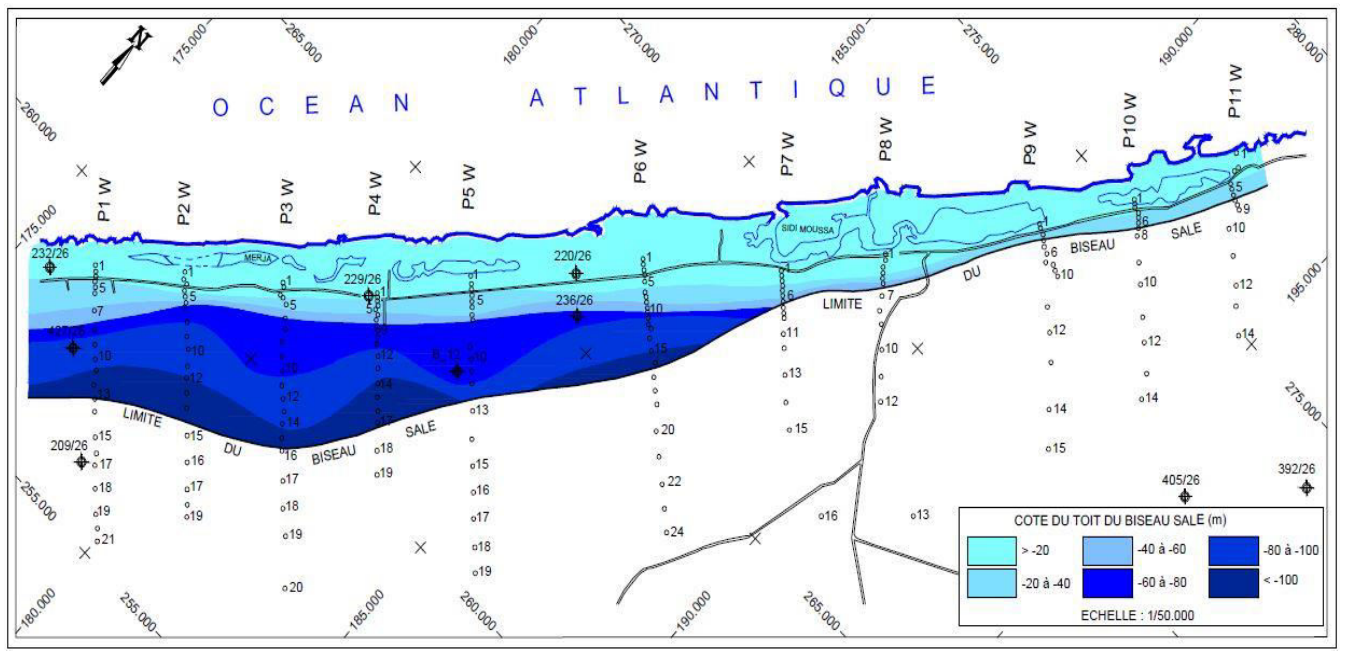

Fig.11. Map of the isohypses of the salted bevel roof (freshwater / saltwater interface)

\section{IV-3-5 - Synthesis map (Fig. 12)}

This map shows the hydrogeological limits of the Hauterivo-Valanginian aquifer system, deduced from the roof maps of Resistant Rd (or Rdv) and the Safi marl wall (roof of Rv or $\mathrm{Cv}$ ), as well as electrical cuts. We observe successively downstream upstream:

The marine invasion limit of the Dridrat limestone, located between the eastern borders of the Merjas and the Safi - El Jadida coastal road. A strip of approximately 300 to $600 \mathrm{~m}$ completely invaded is defined (zone I indicated on the document);

- The limit of invasion of valanginian limestones is behind the first zone: about $1000 \mathrm{~m}$ wide, the Valangin aquifer is saturated with salty water. Only Dridrat limestones would contain "soft" water in Zone II;

- Upstream in zone III, the two carbonate levels seem free of any salt contamination. This area represents about $65 \%$ of the area studied, which represents an uncontaminated area of nearly $110 \mathrm{~km}^{2}$.

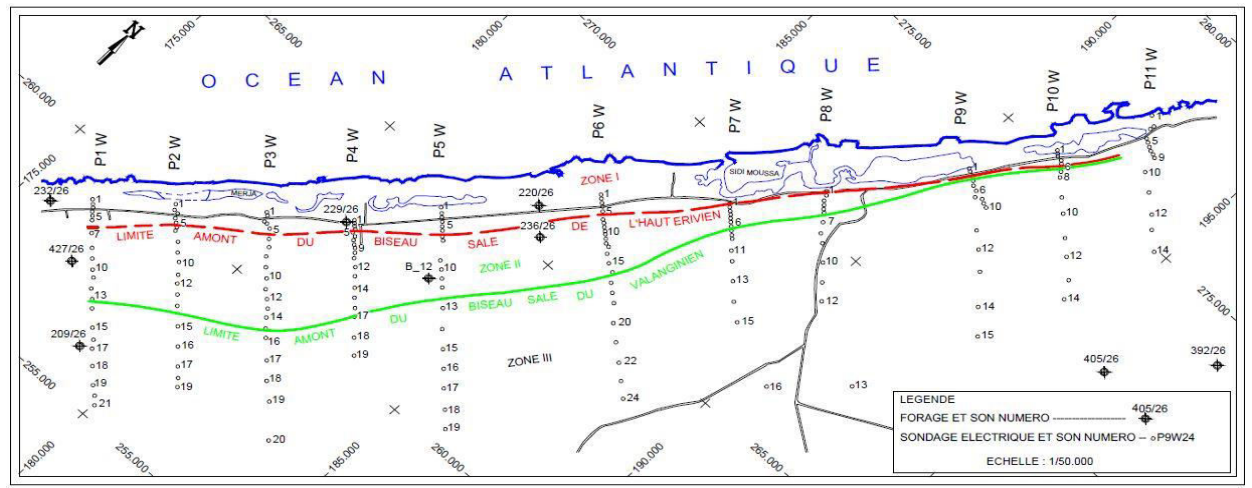

Fig.12. Synthesis map 


\section{V- CONCLUSION}

The electric prospecting by electrical soundings and the hydrogeological synthesis made it possible to propose a diagram on the aquifer system of the Walidia sahel and its downstream limit of equilibrium with the oceanic waters :

1- The salted bevel :

- The salt wedge is followed along the entire ocean edge. The contaminated zone has a fringe with an average width of approximately $2300 \mathrm{~m}(900 \mathrm{~m}$ with a P11 profile at $3800 \mathrm{~m}$ with a P3 profile);

- The differentiation of two distinct boundaries, materializing two salty bevels, storied and of variable importance:

$>$ The upper salty wedge of the Middle Hauterivian (Dridrat limestones) is the least important, remaining at a short distance from the shore $(600-1400 \mathrm{~m})$. this weak invasion of Dridrat limestones is evidence of their good hydrodynamic characteristics;

$>$ The lower saline bevel of the Valanginian penetrates further upstream into probably karstified limestones. The invasion limit is steeper, its upstream end extends up to $3800 \mathrm{~m}$ from the shore.

2- The identification of two aquifer systems :

- The aquifer, represented by Dridrat limestones of about $30 \mathrm{~m}$ of power (when it is not subject to erosion pre-quaternary). The sheet of these limestones is rarely in charge, the piezometric level does not exceed the zero rating;

- Below is a potential aquifer represented by past marly Valanginian limestones. It is separated from Dridrat limestones by Safi marls whose thickness is variable and most often reduced. Locally a significant decrease in the thickness of these marls or a total disappearance can allow the two aquifers to communicate.

3- To the East and North-East of Sidi Moussa, the highlighting of Cretaceous limestones due to a significant rise of the Jurassic formations. In this sector, only the upper Jurassic resistant horizon could present a potential objective. However the interest is limited, due to the presence of anhydrite and gypsum in these levels.

\section{BIBLIOGRAPHY}

1. ONI, 1963 : Etude par prospection électrique dans la plaine des Doukkala. Région de Sidi Bennour, 16 Aoüt-20 Novembre (Compagnie Africaine de Géophysique).

2. M .Ferré and J. P. Ruhard, «Les Bassins des Abda Doukkala et du Sahel d'Azemmour à Safi. Plaines et bassins du Maroc Atlantique » (éditions du service géologique du Maroc), Ressources en Eau du Maroc, Tome II.

3. Aboumaria KH., 1993. Les formations quaternaires du Sahel des Doukkala (Meseta occidentale marocaine) : mise en place et évolution post-sédimentaire. D.E.S., Thèse de 3ème cycle Fac. Sci. Rabat, 8tab .,88 fig., 186p.

4. Akil M., 1990. Les dépôts quaternaires littoraux entre Casablanca et Cap Beddoza (Méseta côtière marocaine) : Etude géomorphologique et sédimentologiques. Thèse doc. Etat, Fac. Sci. Rabat. 417p.

5. Astier, J.L., 1971. Géophysique appliquée à l'hydrogéologie. Masson, Paris.

6. DRPE, 1992. Etude par prospection électrique : Région des Abda et des Doukkala, (21 mars 1990-10 juillet 1990, 08 octobre 1992-15 novembre 1992). GEOATLAS. Tome 1 : texte et planches.

7. Fakir Y., 1991- Caractérisation hydrogéologique et hydrochimique des aquifères côtiers du Sahel de Safi à Oualidia (Méséta côtière- Maroc). Thèse 3éme cycle. Univ. Cadi AYYAD. Marrakech. 
8. Gigout M., 1952. Les ressources en eau souterraine des Doukkala et Abda (Maroc occidental). Rapp. Inéd. Second. Thèse.

9. Merrad S., 1997. Contribution à l'étude hydrogéologique et hydrochimique des aquifères côtiers du Sahel entre Sidi Abed et Oualidia (Maroc). Mém. C.E.A., Univ. Chouaib Doukkali. El Jadida.

10. Souhel A. et El Achheb A., 2000. Cadre géologique des principaux aquifères de la plaine des Doukkala. Actes de la 2 ème session de l'Université de Printemps des Doukkala Abda, Pub. Univ. Chouaib Doukkali-El Jadida, n 3, pp. 71-73. 